\title{
Maria Małgorzata Boużyk, Wychowanie otwarte na religię. Polska Szkota Filozofii Klasycznej o roli religii w wychowaniu, Wydawnic- two UKSW, Warszawa 2013, ss. 382
}

DOI: http://dx.doi.org/I0.12775/PCh.2014.032

Prezentacja książki Marii M. Boużyk posiada sens zawierający się nie tylko w jej jednostkowym wymiarze istotnym dla problematyki relacji między wychowaniem i religią. Sens mówienia o tej książce związany jest z nieobecnym całe lata - nie tylko w okresie PRL-u, ale i w blisko 25-letniej historii po oficjalnym ,zamknięciu” tamtej epoki - obszarem pedagogiki, głównie nurtu katolickiego, o (neo)tomistycznych podstawach filozoficznych, szerzej, obszarem pedagogiki zakorzenionej w realistycznej filozofii wychowania. Rozległość tego obszaru pedagogiki najczęściej dochodziła do głosu w pracach środowiska ${ }^{1}$ związanego z twórczością Mieczysława Gogacza. Rozległość i bogactwo koncepcyjnego myślenia o pedagogice i wychowaniu zakorzenionym w tomizmie i neotomizmie odzwierciedlają Kierunki i koncepcje pedagogiki katolickiej w Polsce 1918-1939 (Kraków 2013) Janiny Kostkiewicz, a świeżość tej filozofii, a zarazem tych podstaw filozoficznych pedagogiki, materializuje się w pracach najmłodszego pokolenia polskich filozofów i filozofów wychowania. Przykładem tego jest znakomite dzieło Konrada Szocika (UJ), Ateizm filozoficzny. Historia i krytyka neotomistyczna (Kraków 2014). Pomijając liczne prace profesora Marcina Karasa (UJ), po

1 Wymienić tu należy obok prac Mieczysława Gogacza [Osoba zadaniem pedagogiki. Wyktady bydgoskie (1997), Wprowadzenie do etyki chronienia osób (1998), Podstawy wychowania (1993) i inne], prace Krzysztofa Kalki, Artura Andrzejuka, Wiesławy Wołoszyn-Spirki, Anny Szudry-Barszcz, Mikołaja Krasnodębskiego i innych. 
książce M. M. Boużyk (UKSW) zarysowuje się krąg badaczy-humanistów odsłaniających tożsamość polskiej humanistyki, w tym filozofii wychowania i pedagogiki, o inspiracjach realizmu filozoficznego (teistycznego).

Nie kwestionując wskazywania źródeł i inspiracji polskiej pedagogiki, tkwiących w niemieckim idealizmie, często nazbyt eksponowanych, właśnie inspiracja realizmem filozoficznym wydaje się wiodąca i dominująca w polskich koncepcjach wychowania i ich historycznym rozwoju. Dlatego właśnie monografia Marii M. Boużyk jest ważna - dopełnia bowiem ten kragg twórczości naukowej.

Książka Marii M. Boużyk dotyczy filozoficznych podstaw wychowania otwartego na religię. Zamiarem autorki jest stworzenie na łamach pracy przestrzeni dla interdyscyplinarnej refleksji (s. 18). Zgodnie ze wstępną tezą, model wychowania otwartego na religię zależy od przyjętej w pedagogice filozoficznej interpretacji istoty religijności i religii - co nie budzi moich wątpliwości jako pedagoga. W budowanym modelu wychowania otwartego na religię wyraża się istota przyjętego rozumienia ,wychowania do religijności” i „wychowania religijnego" (wyznaniowego) - obydwa wymiary stały się przedmiotem dociekań.

Słuszne jest zawarte w tej monografii przekonanie autorki (dochodzące do głosu w wielu kontekstach), że filozoficzny fundament obranego modelu wychowania otwartego na religię (religijnego) pozwala na racjonalizację religijnych treści w obrębie wychowania w konkretnym wyznaniu. Boużyk przytacza istotne argumenty, którymi wykazuje, że jedynie metafizyczne wyjaśnienie faktu religii jest w stanie ustrzec teorię wychowania przed jej instrumentalizacją.

Jednak autorka zbyt nieśmiało eksponuje tu swoją szeroką i doskonale uzasadnioną argumentację - niejako godząc się z małą popularnością Lubelskiej Szkoły Filozofii Klasycznej. Z przesadną skromnością pokazuje ją tylko jako jedno z wielu możliwych rozwiązań, co niewątpliwie jest słusznym stosunkiem do sprawy, lecz argumentacja zbyt skromnie wyeksponowana ginie w potoku treści tej książki.

W Polskiej Szkole Filozofii Klasycznej w ontycznej strukturze bytu ludzkiego wskazywana jest jego egzystencjalna otwartość na Boga. Autorka zatem słusznie tytułuje rozdział 4.1. Człowiek jako ,capax Dei” i słusznie ponadto zauważa, że fakt ten uzasadnia podmiotowość człowieka w procesach go dotyczących. Fakt ten zostaje uznany za podstawę, główny powód i uzasadnienie dla tworzenia modelu wychowania otwartego na religię.

Część pierwsza książki pokazuje poszukiwania takiego modelu. Tutaj bowiem: 
a) uzasadniona jest jego potrzeba oparta na postulacie wychowania do wartości oraz filozoficzne spojrzenie na obecność religii w wychowaniu ze szczególnym wyeksponowaniem realistycznej filozofii wychowania;

b) odsłonięty jest spór o formację humanistyczną, w którym przedmiotem uwagi M. M. Boużyk stają się trzy kategorie rozumiane jako kryteria formacji humanistycznej: dobro moralne, racjonalność wiary i celowość działania;

c) ukazany jest spór o rolę religii w wychowaniu, ze szczególnym wyeksponowaniem roli filozoficznego poznania, w tym metafizyki.

Wartościowe $\mathrm{w}$ tej pracy jest wyłonienie różnic między ewentualnymi modelami wychowania otwartymi na religię, a pochodzącymi z różnic w filozoficznym określaniu kwestii religii w kulturze, samego faktu religii z sięgnięciem przykładowo po scjentystyczną filozofię religii, czy pozaracjonalnej filozofii religii. Pojawiają się tutaj stanowiska W. Diltheya, J. Deweya, postmodernistów (J. Derridy, Ch. Delsol, J-F. Lyotarda), stanowisko Kamińskiego, Zdybickiej, Krapca wobec stanowisk w tej kwestii obcych Polskiej Szkole Filozofii Klasycznej (Kanta, Hegla, Levi-Straussa i strukturalistów, Duméry'ego, Ricoeura i innych). Spór o rolę religii w wychowaniu kończy się odniesieniem do świętości jako wartości realizowanej w religii, jej koncepcja bowiem w sposób zasadniczy - jak wielokrotnie powtarza autorka - wyznacza jakość modelu wychowania otwartego na religię. Świętość ukazana jest w relacji do innych wartości humanistycznych - prawdy, dobra i piękna. Najwięcej miejsca poświęciła autorka analizie świętości w ujęciu chrześcijańskim, kierując się ku świętości jako celowi wychowania religijnego oraz ku kształceniu charakteru.

Część drugą monografii stanowią filozoficzne podstawy wychowania otwartego na religię. Boużyk ma świadomość odsłaniania różnych wariantów wychowania wynikających z otwartości. Rozumie, że fakt ten staje się problemem zawsze wtedy, gdy stajemy wobec ,wyboru jednej z wielu filozoficznych interpretacji” (s. 298) - jak z powyższego wynika, nie jest to tylko problem filozofa, ale także świadomego istoty swych działań pedagoga, który wybiera jeden z nurtów/kierunków pedagogiki (uformowany na podstawie kryterium filozoficznego), jako własny przedmiot badań lub aplikacji w praktykę. Problem ten pojawia się głównie w rozdziale 4 i 5 (czyli dwóch pierwszych rozdziałach części drugiej) - te odnoszą się do:

a) faktu religijności w kontekście ludzkiej godności w jej osobowym (człowiek jako capax Dei, duchowość i cielesność natury) oraz społecznym wymiarze (osoba a społeczeństwo); 
b) rozwoju ludzkiej religijności (z wyeksponowaniem roli poznania i wolności w rozwoju osobowym, oraz relacji między kulturą duchową a cnotą religijności).

Część drugą kończy rozdział 6: Wychowanie religijne: pedagogia chrześcijańska - jak pisze autorka, ważny jest tu ,problem komplementarności filozoficznego rozumienia formacji humanistycznej z religijnym modelem doskonałości człowieka. Konieczne będzie oczywiście odniesienie do konkretnej religii, nie ma bowiem "wychowania religijnego» bezwyznaniowego" (s. 251-252). Jest to szalenie ważna uwaga, szczególnie wobec popularyzowanego dziś sposobu uprawiania pedagogiki chrześcijańskiej.

Autorka pozostaje wobec powyższej kwestii w obszarze chrześcijaństwa, które jest religią, ale praktykowane jest w różnych wyznaniach. $\mathrm{Na}$ teren żadnego wyznania ze swoim modelem wychowania otwartego na religię jednak nie wchodzi, bo wówczas, jako filozof, musiałaby wejść na grunt pedagogiki. Szczególnie dotyczy to rozdziału 6.2. Wychowanie do świętości jako wychowanie do miłości oraz rozdziału 6.3. Teologalna cnota miłości a cnoty kardynalne. Obydwa zagadnienia mają swoje rozwiązania w katolicyzmie jako wyznaniu, w praktyce jego nauczania i jego teoretycznych podstawach: w filozoficznych podstawach pedagogiki katolickiej, o czym Maria M. Boużyk wie, i co pokazuje poprzez odwołania np. do J. Woronieckiego czy K. Wojtyły. Autorka jednak zupełnie nie pozbawia swojej monografii wyznaniowych (katolickich) konkretyzacji, dołączając Aneks, w którym rekonstruuje elementy formacji humanistycznej (jej personalizm, integralność, etykę) w wychowaniu otwartym na religię, w odniesieniu do wyznania katolickiego. Opiera je na katolickich systemach wychowawczych św. Jana Bosko, bł. Marceliny Darowskiej, św. Urszuli Ledóchowskiej. Przywołuje je bliższym dla siebie językiem filozofii, czyniąc lekturę trudniejszą dla pedagoga, lecz dla pedagogiki istotne jest, że zostały tutaj odsłonięte elementy (neo)tomistycznych podstaw tych trzech katolickich systemów wychowawczych.

W omawianej monografii autorka - jako filozof wychowania - uczyniła poważny krok ku pedagogice realistycznego nurtu. W jego rozwój wniosła istotny wkład. Jej twórczość nie tylko jest unikatową wartością dla pedagogiki. Kompetencje autorki, rzadkie wśród filozofów wychowania i pedagogów, są zarazem konieczne i niezbędne na przykład do badań nad historią polskiej myśli pedagogicznej - w jakże szerokim zakresie zakorzenionej w klasycznej filozofii realistycznej (tomistycznej, katolickiej). Pedagogice potrzebni są badacze o takich właśnie kompetencjach choćby po to, by popularyzować nieznaną w świecie polską myśl pedagogiczną. 
Książka ponadto jest wartościowym przykładem humanistycznego i jakościowego zarazem paradygmatu badań pedagogicznych. Podejmowane problemy badane są z głębokim znawstwem, rozwiązywane kompetentnie, z przyjęciem perspektywy pedagogicznej, wyrażającej się najczęściej w zagadnieniach antropologicznych, ujmowanych z perspektywy Polskiej (Lubelskiej) Szkoły Filozofii Klasycznej.

Rola „drugich skrzypiec” we współczesnej kulturze, jaka - ze względów ideologicznych - przypadła klasycznej filozofii realistycznej - w najogólniejszym i wysoce uproszczonym ujęciu - jawi się po lekturze książki Marii M. Boużyk jako przyczyna upadku stanu ducha, moralności, wolności, godności i innych atrybutów człowieka wolnego i odpowiedzialnego. Filozofia realistyczna szkoły lubelskiej jawi się także jako ta, która daje istotne uzasadnienie mechanizmów tego zjawiska.

Janina Kostkiewicz*

\section{Zbigniew Marek, Religia - pomoc czy zagrożenie dla edukacji?, Wy- dawnictwo WAM, Kraków 2014, ss. 248}

DOI: http://dx.doi.org/I0.12775/PCh.2014.033

Książka Religia - pomoc czy zagrożenie dla edukacji? jest kolejną publikacją prof. Zbigniewa Marka, w której prowadzi on naukowe rozważania na temat pedagogiki religii. Swoją refleksję próbuje ukierunkować na religię i wychowanie po to, aby odpowiedzieć na pytanie, czy we współczesnym świecie religia jest pomocna w edukacji, czy też, jak niektórzy sądza, staje się dla niej zagrożeniem. Nie ulega wątpliwości, że czasy, w których przyszło nam żyć, charakteryzują się powierzchownością ludzkiej egzystencji. Coraz bardziej zauważa się relatywizm etyczny, który ma wpływ również na edukację i religijność człowieka oraz jego odniesienia do Boga. Warto zauważyć, że wspomniana powierzchowność dotyka nie tylko osoby wierzące, ale również te, które uważają się za ateistów czy agnostyków. Z prezentowanej refleksji wynika, że powierzchowność, będąca kontrastem dla życia duchowego i odniesienia religijnego, dotyczy niemal wszystkich, zatem ma

* Prof. dr hab. Janina Kostkiewicz jest kierownikiem Zakładu Pedagogiki Szkoły Wyższej i Polskiej Myśli Pedagogicznej w Instytucie Pedagogiki Uniwersytetu Jagiellońskiego. 